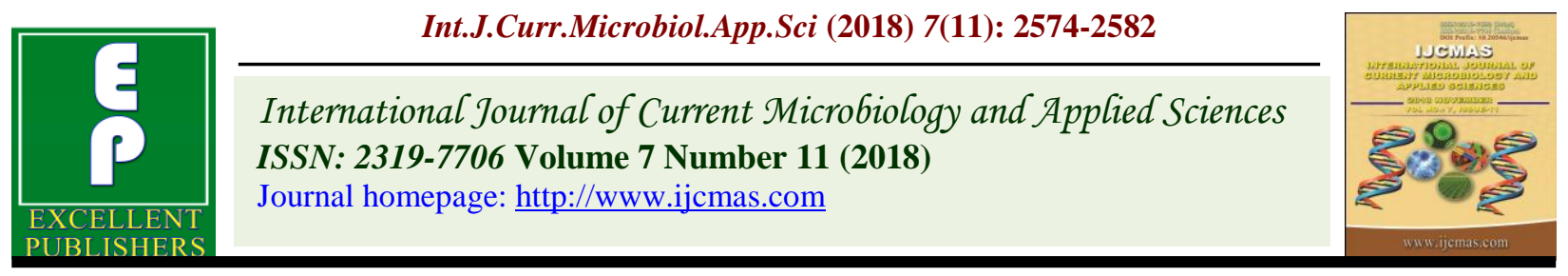

Original Research Article

https://doi.org/10.20546/ijcmas.2018.711.293

\title{
Effect of Drip Fertigation on the Yield and its Attributes of Banana (cv. Martaman-aab) in an Alluvial Soil
}

\author{
T. Basanta Singh ${ }^{1,2 *}$, S.K. Patra ${ }^{1}$, Chongtham Tania ${ }^{2}$, Ch. Premabati Devi ${ }^{2}$, \\ Thokchom Narjit Singh ${ }^{2}$ and Sorokhaibam Romio Singh ${ }^{2}$
}

${ }^{1}$ Bidhan Chandra Krishi Viswavidyalaya, Mohanpur-741252, West Bengal, India

${ }^{2}$ ICAR Research Complex for NEH Region, Manipur Centre, Lamphelpat -795004, Imphal

*Corresponding author

A B S T R A C T

Keywords

Drip fertigation,

Banana, Yield,

Yield attributes,

Alluvial soil

Article Info

Accepted:

18 October 2018

Available Online:

10 November 2018
The field experiment was conducted at the Research Farm of Bidhan Chandra Krishi Viswavidyalaya, West Bengal to study the effect of drip fertigation on the fruit character and yield banana during 2011 to 2013). The drip fertigation was done at four evapotranspiration (ET) based irrigation levels $\left(D_{1}=0.6 \mathrm{ET}, \mathrm{D}_{2}=0.8 \mathrm{ET}, \mathrm{D}_{3}=1.0 \mathrm{ET}\right.$ for drip and surface irrigation (S) at IW/CPE 1.0) and at three fertilizer levels of recommended doses of fertilizer (RDF) viz., $F_{1}=60 \%$ RDF, $F_{2}=80 \%$ RDF and $F_{3}=100 \%$ RDF laid out in factorial randomized block design with three replications. The drip irrigation level D3 gave the highest fruit yield (40.8 t/ha) followed by that of D2 (40.2 t/ha) and D1 (34.0 t/ha) and the lowest for surface irrigation $(29.0 \mathrm{t} / \mathrm{ha})$. The higher fertilizer dose (F3) produced the highest yield (39.8 t/ha). The treatment combination, D3F3 gave the positive effect on finger and bunch characteristics. The combination also gave the maximum yield (44.6 t/ha for main and $42.5 \mathrm{t} / \mathrm{ha}$ for ratoon crop). The lowest yield was registered under conventional irrigation and fertilization system (34.2 t/ha) resulting 27\% lesser yield compared with treatment D3F3.

\section{Introduction}

Banana is one of the most important leading fruit crop in India. It accounts for the production of 16.5 million tonnes annually from an area of about 5 lakh hectares. It is also one of the leading fruit crops of West Bengal. The loamy soils of Gangetic alluvium are extremely suitable for the cultivation of banana. The average productivity of the crop is 18 to 20 tonnes per hectare in the state, while country's productivity is $34 \mathrm{t} / \mathrm{ha}$ (Singh, 2007). So, there is ample scope to increase the productivity of this crop. The spatial and temporal variation in the distribution of rainfall is expanding across the world. The drought like problems are common even in monsoon months also, wherein life-saving or supplemental irrigation is must. In India, drip fertigation is extensively used in the banana cultivation. The Horticulture Mission Project under the Government of India in collaboration with the state government has implemented and adopted the exclusive programme of micro-irrigation with the subsidy to the extent of 50 percent, but the 
state is lagging behind on large scale implementation. The farmers in India generally follow conventional surface method of irrigation in banana cultivation which is quite inefficient and non-remunerative. The major portion of cost is incurred in hiring labour for irrigation (More et al., 2005). Hence, there is need to encourage farmers to adopt the drip irrigation method, even the initial capital is high but labour saving at long run. Moreover, the banana farmers are being constrained with technical expertise to adopt drip irrigation system. In this backdrop, it is worthwhile to study the effect of drip fertigation on the yield and its attributes of banana on a sandy loam soil.

\section{Materials and Methods}

The field experiment was conducted during the year 2012 AND 2013 at the Central Research Farm, Gayeshpur, Bidhan Chandra Krishi Viswavidyalaya West Bengal encompassing the New Alluvial Zone $(9.75 \mathrm{~m}$ above MSL and $23^{\circ} \mathrm{N}$ and $89^{\circ} \mathrm{E}$ coordinate). The $\mathrm{pH}, \mathrm{EC}$, organic carbon percent, $\mathrm{N}, \mathrm{P}$ and $\mathrm{K}$ soil of the research field were respectively, $6.9,0.1 \mathrm{dS} / \mathrm{m}, 4.6,196.7 \mathrm{~kg} / \mathrm{ha}, 18.9 \mathrm{~kg} / \mathrm{ha}$ and $135.6 \mathrm{~kg} / \mathrm{ha}$. The groundwater having $\mathrm{pH}$ of 7.6 and $\mathrm{EC}$ of $0.62 \mathrm{dS} / \mathrm{m}$ was used to mix with fertilizer for irrigation. Healthy sword suckers (2-3 leaf) weighing around $1.5-2 \mathrm{~kg}$ each (2.02.5 month old) of banana cv. Martaman (AAB group) were planted (spacing $=2 \mathrm{~m} \times 2 \mathrm{~m}$ ) in the square pattern. The ratoon was maintained by retaining only one sucker per plant.

\section{Estimation of irrigation water requirement}

The reference crop evapotranspiration (ETo) was taken as the basis to calculate of crop water requirement (Doorenbos and Pruitt, 1977). Drip irrigation was provided to replenish 100, 80 and $60 \%$ of the ETo which is multiplied by suitable crop co-efficient $(\mathrm{Kc})$ values according to the crop stage, their product yields crop evapotranspiration (ETc). ETo was calculated by multiplying of pan evaporation (Ep) and pan factor $(\mathrm{Kp}=0.8)$. The daily Ep was recorded from the USWB classA pan installed inside the research farm. The monthly value of $\mathrm{Kc}$ for banana varied from 0.55 to 1.1 during first year and 1.0 to 1.2 during second year for three crop stages (Allen et al., 1998). The volume of water required per plot was computed based on the equation given by Vermeiren and Jobling (1980). The drip fertigation was done at four evapotranspiration (ET) based irrigation levels $\left(\mathrm{D}_{1}=0.6 \mathrm{ET}, \mathrm{D}_{2}=0.8 \mathrm{ET}, \mathrm{D}_{3}=1.0 \mathrm{ET}\right.$ for drip and surface irrigation (S) at IW/CPE 1.0) and at three fertilizer levels of recommended doses of fertilizer (RDF) viz., $\mathrm{F}_{1}=60 \%$ RDF, $\mathrm{F}_{2}=80 \% \mathrm{RDF}$ and $\mathrm{F}_{3}=100 \%$ RDF laid out in factorial randomized block design with three replications. In case of surface irrigation, water was applied at IW/CPE 1.0 which is scheduled at 15-20 days' interval).

\section{Fertilizer source and scheduling}

Water soluble and cheaply available conventional fertilizers were used for the fertigation. Nitrogen was supplied through urea $(46 \% \mathrm{~N})$ as its primary source. Diammonium phosphate $\left(46 \% \mathrm{P}_{2} \mathrm{O}_{5}\right.$ and $\left.18 \% \mathrm{~N}\right)$ was used to supply phosphorus and also as secondary source of $\mathrm{N}$ and muriate of potash $\left(60 \% \mathrm{~K}_{2} \mathrm{O}\right)$ as the $\mathrm{K}$ source. These fertilizers are quite soluble in water, compatible to mixing together and convenient for drip fertigation (Kafkafi and Kant, 2005). The DAP fertilizer was dissolved in water one day before the irrigation with intermittent stirring and the suspensions were removed by filtering. The drip fertigation were scheduled in splits by targeting the active growth stages of banana. The fertigation was commenced nine weeks after planting. The nitrogen fertilizer was applied in 20 splits, phosphorus in two splits and potassium in nine splits. In conventional soil application of fertilizers 
followed by surface irrigation at IW/CPE 1.0, the whole amount of phosphorus and 50 percent of nitrogen and potassium were broadcasted uniformly after seven weeks of planting around $30 \mathrm{~cm}$ to $70 \mathrm{~cm}$ distance from the plant base. The remaining nitrogen $(50 \%)$ was applied in 3 equal splits at 5,7 and 9 months after planting and remaining potassium (50\%) was applied at 9 months after planting. The remaining fertilizers schedules for 80 percent and 60 percent of $\mathrm{RDF}$ were calculated accordingly.

\section{Estimation for yield and its attributes}

The numbers of finger per hand and hands per bunch were recorded. The last hand having less than half number of developed finger of an average normal hand was not recorded. The fruit yield was computed from bunch weight and expressed in tonnes per hectare. For measuring the bunch weight, the bunch axis (peduncle) was cut above the first hand at the level of the last scar and immediately below the last hand and the bunch weight was determined by weighing individual bunches with a weighing balance. The length of the bunch was determined at $10 \mathrm{~cm}$ above and below the level of first hand and the last hand. Number of hands per bunch was obtained by simply counting the number of hands on each bunch. The number of finger per bunch was obtained by simply counting the number of fingers on each hand. Numbers of hands were counted in spiral direction in accordance with the natural position of the bunch. For recording the morphological characters of fruit, the central fruit in the top row of the second hand was as representative finger. Fruit weight was determined by weighing individual fruits on a balance and expressed in gram. For finger length and girth, the fruits in the top row of the second hand were regarded as representative finger. The length of finger was measured with a measuring tape from the base of pedicel to the tip in centimeter. The girth of finger was measured at three positions namely base, middle and tip and the average value was recorded. Pulp and peel weight were determined after peeling out the finger and weighing them separately and expressed as pulp-peel ratio by dividing the pulp weight by the weight of peel. Most of the above parameters were measured by following the standard methods developed by Gottreich et al., (1964).

\section{Statistical analysis}

To compare the effect of irrigation and fertilizer levels on yield and fruit characteristics, data were statistically analyzed following Gomez and Gomez (1984). The statistical differences of the data generated for each year and their pooled values were tested with least significant difference (LSD) at 5\% probability level using analysis of variance technique (ANOVA). The standard error of means $(\mathrm{SEm} \pm$ ) and critical difference $(\mathrm{CD})$ at $5 \%$ level of significance were calculated to compare the treatment means. To observe the significance of differences between irrigation and fertilizer, the pairs of interaction mean values $\left(1^{\text {st }}\right.$ and $2^{\text {nd }}$ year) were compared by the Duncan's Multiple Range Test (DMRT) at probability $<0.05$ using SPSS software (Version 16.0). The means for groups in homogeneous sets are displayed with similar letters.

\section{Results and Discussion}

\section{Finger characteristics}

The finger characteristics of plant and ratoon crop were significantly influenced by varied irrigation regimes and NPK fertilizer levels (Table 1). Among irrigation levels, the number of finger per bunch was significantly higher in drip irrigation at $100 \%$ of evaporation replenishment $\left(\mathrm{D}_{3}\right)$ than the other irrigation regimes. However, finger length, finger 
weight and finger girth shown by $\mathrm{D}_{3}$ were statistically at par with drip irrigation at $80 \%$ of evaporation replenishment $\left(\mathrm{D}_{2}\right)$, but was significantly better than remaining two irrigation regimes. The plants receiving $100 \%$ $\mathrm{RDF}\left(\mathrm{F}_{3}\right)$, on an average, produced significantly the higher number of finger per bunch (129.9), finger length $(14.0 \mathrm{~cm})$, finger weight $(132.9 \mathrm{~g})$ and finger girth $(12.9 \mathrm{~cm})$ over the other fertilizer levels tried. The treatment combinations of $\mathrm{D}_{3} \mathrm{~F}_{3}$ and $\mathrm{D}_{2} \mathrm{~F}_{3}$, on an average, produced the comparative performances in terms of higher number of fingers per bunch (137.6 and 137.0), finger length (16.0 and $15.5 \mathrm{~cm})$, finger weight (145.2 and $143.5 \mathrm{~g})$ and finger girth (13.5 and $13.4 \mathrm{~cm})$ as compared with rest of the treatment combinations. It was conspicuous that the higher levels of water and fertilizer produced more number of fingers per bunch, finger length, finger weight, and finger girth. These results are in agreement with the findings of Mahalakshmi et al., (2003), Badgujar et al., (2004), Kumar and Pandey (2008). Number of fingers per bunch can be considered as an indicator of yield (Dorel et al., 2008). The irrigation and fertilizer levels and their interactions had significant influence on the pulp weight, peel weight and pulp-peel ratio as in bunch characteristics. Drip irrigation $D_{2}$ and $D_{3}$ and fertilizer levels $F_{3}$ and $F_{2}$ were comparable on these parameters and were significantly better than remaining respective treatments. The surface irrigation, on the other hand, recorded lowest results and were inferior to that of the drip irrigation levels. Kar and Firake (2002) reported that the highest pulp-peel ratio was observed with $100 \%$ recommended dose of NPK, while Kumar and Pandey (2008) recorded the maximum pulp-peel ratio with $75 \%$ recommended dose of NPK. Among the interaction levels, the treatments of $\mathrm{D}_{2} \mathrm{~F}_{2}$ (4.2) and $\mathrm{D}_{3} \mathrm{~F}_{3}$ (4.3) produced higher pulp-peel ratio, which was closely followed by $\mathrm{D}_{2} \mathrm{~F}_{3}$ (4.1). Drip fertigation as a whole increased the pulp-peel ratio as compared to surface irrigation and conventional soil fertilization. These results are in agreement with the findings of Dahiwalkar et al., (2004).

\section{Bunch characteristics}

The bunch characteristics of plant and ratoon crop were significantly influenced by the irrigation regimes and fertilizer levels (Table $2)$. Irrespective of plant types, the average bunch weight $(16.3 \mathrm{~kg})$, bunch length $(53.8$ $\mathrm{cm}$ ) and hands per bunch (8.4) were found to be highest in drip irrigation at $100 \%$ of evaporation replenishment $\left(\mathrm{D}_{3}\right)$ which was at par with drip irrigation at $80 \%$ of evaporation replenishment $\left(\mathrm{D}_{2}\right)$, and was superior to the remaining two levels of irrigation. The conventional surface irrigation exhibited poor performance in the development of bunch characters. Application of $100 \%$ recommended dose of NPK (RDF) recorded significantly highest bunch weight $(15.9 \mathrm{~kg})$, bunch length $(53.8 \mathrm{~cm})$ and hands per bunch (8.5) among various fertilizer levels studied. Among the interaction levels, $\mathrm{D}_{2} \mathrm{~F}_{3}$ combination gave significantly higher bunch characters in plant as well as ratoon crop, but was statistically at par with that of $\mathrm{D}_{2} \mathrm{~F}_{2}$ and $\mathrm{D}_{2} \mathrm{~F}_{3}$ combinations. It was also revealed that the increasing levels of drip irrigation and fertigation increased bunch characteristics and was superior to the conventional method of surface irrigation and soil fertilization. These indicated the beneficial effects of drip fertigation system in influencing the bunch characteristics mainly by way of higher levels of water and nutrients supply in crop root zone at the right time and facilitated subsequent absorption. Higher bunch weight at higher water levels could be attributed to an increased vigour and improved physiological activity of plants (Mahalakshmi et al., 2003). These results were in accordance with the findings of Kavino et al., (2002) and Badgujar et al., (2004). 


\begin{tabular}{|c|c|c|c|c|c|c|c|c|c|c|c|c|c|c|c|}
\hline \multirow{3}{*}{$\begin{array}{l}\text { Treatments } \\
\text { Irrigation } \\
\text { (I) }\end{array}$} & \multicolumn{12}{|c|}{ Table.1 Effect of different irrigation and fertilizer treatments on finger characteristics of banana } & \multirow{2}{*}{\multicolumn{3}{|c|}{ Pulp/ Peel ratio }} \\
\hline & \multicolumn{3}{|c|}{ Finger/ bunch } & \multicolumn{3}{|c|}{ Finger length $(\mathrm{cm})$} & \multicolumn{3}{|c|}{ Finger Weight $(\mathrm{g})$} & \multicolumn{3}{|c|}{ Finger girth $(\mathrm{cm})$} & & & \\
\hline & Crop I & Crop II & Pooled & Crop I & Crop II & Pooled & Crop I & Crop II & Pooled & Crop I & crop II & Pooled & Crop I & $\begin{array}{c}\text { Crop } \\
\text { II }\end{array}$ & Pooled \\
\hline $\mathrm{D}_{1}$ & 113.8 & 106.7 & 110.2 & 13.2 & 12.5 & 12.8 & 128.2 & 119.0 & 123.6 & 11.7 & 11.3 & 11.5 & 3.8 & 3.8 & 3.8 \\
\hline $\mathbf{D}_{2}$ & 128.7 & 120.1 & 124.4 & 14.8 & 14.3 & 14.6 & 139.8 & 130.2 & 135.0 & 12.7 & 12.6 & 12.6 & 4.1 & 4.0 & 4.0 \\
\hline $\mathbf{D}_{3}$ & 134.8 & 123.9 & 129.4 & 15.1 & 14.6 & 14.8 & 143.7 & 131.2 & 137.4 & 13.2 & 12.9 & 13.0 & 3.9 & 4.1 & 4.0 \\
\hline $\mathbf{S}$ & 101.1 & 95.0 & 98.0 & 10.9 & 9.7 & 10.3 & 105.0 & 101.4 & 103.2 & 11.5 & 10.2 & 10.9 & 3.7 & 3.7 & 3.7 \\
\hline SEm ( \pm$)$ & 0.408 & 0.501 & 0.323 & 0.256 & 0.263 & 0.183 & 0.695 & 0.400 & 0.401 & 0.304 & 0.084 & 0.157 & 0.061 & 0.065 & 0.045 \\
\hline CD (0.05) & 1.197 & 1.471 & 0.921 & 0.750 & 0.771 & 0.523 & 2.039 & 1.174 & 1.143 & 0.890 & 0.245 & 0.449 & 0.180 & 0.191 & 0.127 \\
\hline \multicolumn{16}{|l|}{ Fertilizer $(F)$} \\
\hline$F_{1}$ & 100.9 & 93.0 & 96.9 & 12.5 & 11.6 & 12.1 & 118.4 & 108.4 & 113.4 & 11.4 & 10.6 & 11.0 & 3.7 & 3.7 & 3.7 \\
\hline$F_{2}$ & 123.4 & 116.2 & 119.8 & 13.6 & 13.0 & 13.3 & 132.4 & 123.9 & 128.2 & 12.3 & 12.0 & 12.1 & 3.9 & 3.9 & 3.9 \\
\hline $\mathbf{F}_{3}$ & 134.6 & 125.1 & 129.9 & 14.3 & 13.7 & 14.0 & 136.7 & 129.0 & 132.9 & 13.2 & 12.7 & 12.9 & 4.0 & 4.1 & 4.0 \\
\hline $\operatorname{SEm}( \pm)$ & 0.353 & 0.434 & 0.280 & 0.221 & 0.228 & 0.159 & 0.602 & 0.347 & 0.347 & 0.263 & 0.072 & 0.136 & 0.053 & 0.056 & 0.039 \\
\hline CD (0.05) & 1.036 & 1.274 & 0.798 & 0.650 & 0.668 & 0.453 & 1.766 & 1.017 & 0.990 & 0.771 & 0.212 & 0.389 & 0.156 & 0.165 & 0.110 \\
\hline \multicolumn{16}{|c|}{ rigation $x$ Fertilizer } \\
\hline $\mathbf{D}_{1} \mathbf{F}_{1}$ & 87.5 & 82.1 & $84.8^{\mathrm{a}}$ & 12.9 & 11.5 & 12.2 & 110.2 & 104.6 & $107.4^{\text {ab }}$ & 10.7 & 10.4 & $10.6^{\mathbf{a b}}$ & 3.7 & 3.5 & $3.6^{\mathrm{b}}$ \\
\hline $\mathbf{D}_{1} \mathbf{F}_{2}$ & 123.2 & 115.1 & $119.2^{\mathrm{c}}$ & 13.0 & 12.5 & 12.7 & 133.3 & 123.4 & $128.3^{\text {cd }}$ & 11.8 & 11.5 & $11.6^{\mathrm{bc}}$ & 3.8 & 3.9 & $3.8^{\mathbf{b c}}$ \\
\hline $\mathbf{D}_{1} \mathbf{F}_{3}$ & 130.7 & 122.8 & $126.7^{\text {cde }}$ & 13.6 & 13.5 & 13.5 & 141.2 & 129.0 & $135.1^{\text {cd }}$ & 12.7 & 12.1 & $12.4^{\text {cd }}$ & 3.8 & 3.9 & $3.9^{\text {bcd }}$ \\
\hline $\mathbf{D}_{2} \mathbf{F}_{1}$ & 107.0 & 96.6 & $101.8^{b}$ & 13.4 & 12.2 & 12.8 & 125.3 & 112.5 & $118.9^{\mathbf{b c}}$ & 11.6 & 11.3 & $11.4^{\mathbf{b c}}$ & 3.9 & 3.8 & $3.9^{\mathbf{b c}}$ \\
\hline $\mathbf{D}_{2} \mathbf{F}_{2}$ & 137.9 & 131. & $134.5^{\mathrm{de}}$ & 15.4 & 15.3 & 15.4 & 146.7 & 138.4 & $142.6^{d}$ & 13.1 & 13.1 & $13.1^{d}$ & 4.2 & 4.2 & $4.2^{\mathrm{e}}$ \\
\hline $\mathbf{D}_{2} \mathbf{F}_{3}$ & 141.3 & 132.7 & $137.0^{\mathrm{e}}$ & 15.6 & 15.5 & 15.5 & 147.3 & 139.6 & $143.5^{\mathrm{d}}$ & 13.4 & 13.3 & $13.4^{d}$ & 4.1 & 4.1 & $4.1^{\text {de }}$ \\
\hline $\mathbf{D}_{3} \mathbf{F}_{1}$ & 128.2 & 112.4 & $120.3^{\text {cd }}$ & 14.0 & 13.7 & 13.8 & 138.3 & 118.5 & $128.4^{\mathrm{cd}}$ & 12.6 & 12.4 & $12.5^{\mathrm{cd}}$ & 3.8 & 4.0 & $3.9^{\mathrm{cd}}$ \\
\hline $\mathbf{D}_{3} \mathbf{F}_{2}$ & 134.0 & 126.4 & $130.2^{\text {cde }}$ & 15.0 & 14.4 & 14.7 & 143.5 & 133.8 & $138.6^{d}$ & 12.9 & 13.2 & $13.1^{d}$ & 3.7 & 3.8 & $3.8^{\mathbf{b c}}$ \\
\hline $\mathbf{D}_{3} \mathbf{F}_{3}$ & 142.3 & 133.0 & $137.6^{\mathrm{e}}$ & 16.2 & 15.7 & 16.0 & 149.2 & 141.2 & $145.2^{d}$ & 14.0 & 13.1 & $13.5^{\mathrm{d}}$ & 4.1 & 4.4 & $4.3^{\mathrm{e}}$ \\
\hline $\mathbf{S F}_{1}$ & 80.8 & 81.0 & $80.9^{\mathbf{a}}$ & 9.7 & 9.1 & 9.4 & 99.7 & 97.9 & $98.8^{\mathbf{a}}$ & 10.6 & 8.4 & $9.5^{\mathrm{a}}$ & 3.3 & 3.4 & $3.4^{\mathrm{a}}$ \\
\hline $\mathbf{S F}_{2}$ & 98.3 & 92.0 & $95.2^{\mathbf{a b}}$ & 11.1 & 9.8 & 10.4 & 106.1 & 100.1 & $103.1^{\mathrm{ab}}$ & 11.2 & 10.2 & $10.7^{\mathbf{a b}}$ & 3.8 & 3.6 & $3.7^{\mathbf{b c}}$ \\
\hline $\mathbf{S F}_{3}$ & 124.2 & 111.9 & $118.1^{\mathrm{c}}$ & 11.9 & 10.3 & 11.1 & 109.3 & 106.3 & $107.8^{\mathbf{a b}}$ & 12.7 & 12.1 & $12.4^{\mathrm{cd}}$ & 3.9 & 4.0 & $3.9^{\text {cd }}$ \\
\hline SEm ( \pm$)$ & 0.707 & 0.869 & 0.560 & 0.443 & 0.455 & 0.318 & 1.204 & 0.693 & 0.695 & 0.526 & 0.145 & 0.273 & 0.106 & 0.113 & 0.077 \\
\hline CD (0.05) & 2.073 & 2.547 & 1.596 & NS & NS & NS & 3.532 & 2.034 & 1.980 & NS & 0.425 & 0.776 & NS & NS & 0.221 \\
\hline
\end{tabular}




\begin{tabular}{|c|c|c|c|c|c|c|c|c|c|c|c|c|}
\hline \multirow{2}{*}{$\begin{array}{c}\text { Treatments } \\
\text { Irrigation }(I)\end{array}$} & \multicolumn{3}{|c|}{ Bunch weight (kg) } & \multicolumn{3}{|c|}{ Bunch Length $(\mathrm{cm})$} & \multicolumn{3}{|c|}{ Hand/bunch } & \multicolumn{3}{|c|}{ Yield (t/ha) } \\
\hline & Crop I & Crop II & Pooled & Crop I & Crop II & Pooled & Crop I & Crop II & Pooled & Crop I & crop II & Pooled \\
\hline $\mathbf{D}_{1}$ & 14.3 & 12.9 & 13.6 & 49.2 & 47.3 & 48.2 & 7.3 & 6.7 & 7.0 & 35.7 & 32.3 & 34.0 \\
\hline $\mathbf{D}_{2}$ & 16.5 & 15.6 & 16.1 & 55.0 & 52.1 & 53.6 & 8.3 & 8.1 & 8.2 & 41.3 & 39.1 & 40.2 \\
\hline $\mathbf{D}_{3}$ & 16.6 & 16.0 & 16.3 & 55.2 & 52.4 & 53.8 & 9.0 & 7.9 & 8.4 & 41.5 & 40.0 & 40.8 \\
\hline $\mathbf{S}$ & 12.2 & 11.0 & 11.6 & 42.8 & 39.7 & 41.2 & 7.2 & 6.3 & 6.8 & 30.5 & 27.5 & 29.0 \\
\hline $\operatorname{SEm}( \pm)$ & 0.22 & 0.26 & 0.17 & 0.169 & 0.307 & 0.175 & 0.153 & 0.151 & 0.107 & 0.560 & 0.652 & 0.430 \\
\hline CD (0.05) & 0.66 & 0.77 & 0.49 & 0.497 & 0.900 & 0.500 & 0.448 & 0.442 & 0.306 & 1.642 & 1.913 & 1.225 \\
\hline \multicolumn{13}{|l|}{ Fertilizer $(F)$} \\
\hline $\mathbf{F}_{1}$ & 12.9 & 11.8 & 12.4 & 44.4 & 42.3 & 43.4 & 7.0 & 6.2 & 6.6 & 32.2 & 29.6 & 30.9 \\
\hline $\mathbf{F}_{2}$ & 15.4 & 14.5 & 14.9 & 51.9 & 49.1 & 50.5 & 8.2 & 7.4 & 7.8 & 38.4 & 36.1 & 37.3 \\
\hline $\mathbf{F}_{3}$ & 16.5 & 15.4 & 15.9 & 55.3 & 52.3 & 53.8 & 8.8 & 8.2 & 8.5 & 41.2 & 38.5 & 39.8 \\
\hline $\operatorname{SEm}( \pm)$ & 0.19 & 0.23 & 0.15 & 0.147 & 0.266 & 0.152 & 0.132 & 0.131 & 0.093 & 0.485 & 0.565 & 0.372 \\
\hline CD (0.05) & 0.57 & 0.66 & 0.42 & 0.430 & 0.780 & 0.433 & 0.388 & 0.383 & 0.265 & 1.422 & 1.657 & 1.061 \\
\hline \multicolumn{13}{|c|}{ Irrigation $x$ Fertilizer } \\
\hline $\mathbf{D}_{1} \mathbf{F}_{1}$ & 12.1 & 10.5 & $11.3^{\mathbf{b}}$ & 43.4 & 42.0 & $42.7^{\mathbf{b c}}$ & 6.3 & 5.7 & $6.0^{\mathrm{a}}$ & 30.2 & 26.3 & $28.2^{\mathbf{b}}$ \\
\hline $\mathbf{D}_{1} \mathbf{F}_{2}$ & 14.6 & 13.8 & $14.2^{d}$ & 50.5 & 49.1 & $49.8^{\text {de }}$ & 7.7 & 6.7 & $7.2^{\mathbf{a b c}}$ & 36.4 & 34.5 & $35.5^{d}$ \\
\hline$D_{1} F_{3}$ & 16.2 & 14.5 & $15.3^{\text {def }}$ & 53.7 & 50.9 & $52.3^{\text {ef }}$ & 8.0 & 7.7 & $7.8^{\text {bcde }}$ & 40.5 & 36.2 & $38.3^{\text {def }}$ \\
\hline $\mathrm{D}_{2} \mathbf{F}_{1}$ & 14.6 & 13.2 & $13.9^{d}$ & 46.7 & 44.5 & $45.6^{\mathrm{cd}}$ & 6.7 & 6.3 & $6.5^{\mathbf{a b}}$ & 36.5 & 33.0 & $34.8^{d}$ \\
\hline $\mathbf{D}_{2} \mathbf{F}_{2}$ & 17.4 & 16.7 & $17.1^{\mathrm{fg}}$ & 58.8 & 55.1 & $57.0^{\mathbf{g}}$ & 9.0 & 9.0 & $9.0^{\text {de }}$ & 43.5 & 41.8 & $42.6^{\mathrm{fg}}$ \\
\hline$D_{2} F_{3}$ & 17.6 & 17.0 & $17.3^{\mathrm{g}}$ & 59.5 & 56.7 & $58.1^{\mathrm{g}}$ & 9.3 & 9.0 & $9.2^{\mathbf{e}}$ & 44.0 & 42.5 & $43.3^{\mathrm{g}}$ \\
\hline $\mathrm{D}_{3} \mathrm{~F}_{1}$ & 15.3 & 15.1 & $15.2^{\mathrm{de}}$ & 48.0 & 46.1 & $47.1^{\mathrm{cd}}$ & 8.3 & 7.3 & $7.8^{\text {bcde }}$ & 38.2 & 37.8 & $38.0^{\text {de }}$ \\
\hline$D_{3} F_{2}$ & 16.7 & 15.9 & $16.3^{\text {efg }}$ & 56.5 & 53.7 & $55.1^{\mathrm{fg}}$ & 9.0 & 7.7 & $8.3^{\text {cde }}$ & 41.8 & 39.8 & $40.8^{\mathrm{eg}}$ \\
\hline$D_{3} F_{3}$ & 17.8 & 17.0 & $17.4^{\mathrm{g}}$ & 61.1 & 57.5 & $59.3^{\mathrm{g}}$ & 9.7 & 8.7 & $9.2^{\mathrm{e}}$ & 44.6 & 42.5 & $43.5 f^{g}$ \\
\hline $\mathrm{SF}_{1}$ & 9.5 & 8.5 & $9.0^{\mathbf{a}}$ & 39.4 & 36.7 & $38.1^{\mathrm{a}}$ & 6.7 & 5.3 & $6.0^{\mathrm{a}}$ & 23.8 & 21.3 & $22.6^{\mathrm{a}}$ \\
\hline $\mathrm{SF}_{2}$ & 12.8 & 11.4 & $12.1^{\mathbf{b c}}$ & 41.8 & 38.4 & $40.1^{\mathbf{a b}}$ & 7.0 & 6.3 & $6.7^{\mathbf{a b}}$ & 32.0 & 28.5 & $30.3^{\mathbf{b c}}$ \\
\hline $\mathrm{SF}_{3}$ & 14.2 & 13.1 & $13.7^{\mathbf{c d}}$ & 47.0 & 44.0 & $45.5^{\mathrm{cd}}$ & 8.0 & 7.3 & $7.7^{\text {bcd }}$ & 35.6 & 32.8 & $34.2^{\text {cd }}$ \\
\hline $\operatorname{SEm}( \pm)$ & 0.388 & 0.452 & 0.298 & 0.294 & 0.532 & 0.304 & 0.264 & 0.261 & 0.186 & 0.970 & 1.130 & 0.744 \\
\hline CD $(0.05)$ & 1.138 & 1.325 & 0.849 & 0.861 & 1.560 & 0.866 & 0.775 & 0.766 & 0.529 & 2.844 & 3.313 & 2.122 \\
\hline
\end{tabular}




\section{Yield}

The different levels of irrigation and fertilizer had pronounced effects on the fruit yield of plant and ratoon crop (Table 2). Among four irrigation levels, $\mathrm{D}_{3}$ registered higher yield of $41.5 \mathrm{t} / \mathrm{ha}$ for plant crop and $40.0 \mathrm{t} / \mathrm{ha}$ for ratoon crop, which was statistically at par with drip irrigation $\mathrm{D}_{2}$ exhibiting yield of 41.3 t/ha for plant crop and $39.1 \mathrm{t} /$ ha for ratoon crop. Drip irrigation at $60 \%$ of evaporation replenishment $\left(\mathrm{D}_{1}\right)$ resulted in significant decrease in yield of plant $(35.7 \mathrm{t} / \mathrm{ha})$ and ratoon $(32.3 \mathrm{t} / \mathrm{ha})$ crop as compared with the former two treatments. The surface irrigation (S), on the other hand, recorded significantly lowest yield of $30.5 \mathrm{t} / \mathrm{ha}$ for plant crop and $27.5 \mathrm{t} / \mathrm{ha}$ for ratoon crop. The pooled value also revealed the same trend as in plant and ratoon crop. This improvement in yield of both the crops might be ascribed to the significant increase in finger and bunch characteristics of banana like hands per bunch, bunch weight and finger weight. Similar findings were corroborated by Goenaga and Irizarry (1998) and Shelke et al., (1998). Among the three levels of NPK fertilizers, the progressive increment in fertilizer levels resulted in significant increase in fruit yield of plant and ratoon crop. On an average, the highest fruit yield of $39.8 \mathrm{t} / \mathrm{ha}$ was recorded under $F_{3}$, which was closely followed by $F_{2}(37.3 \mathrm{t} / \mathrm{ha}$ ) and the lowest yield of $30.9 \mathrm{t} / \mathrm{ha}$ was recorded under $\mathrm{F}_{1}$. This increase in yield under higher fertilizer level was largely due to improvement in the nutrient absorption by crop (Mahalakshmi et al., 2001; Kavino et al., 2002), which in turn influenced the increase in size and weight (Srinivas et al., 2001).

The interaction between irrigation and fertilizer levels had significant effect on fruit yield of plant and ratoon crop. Maximum yield of $44.6 \mathrm{t} / \mathrm{ha}$ for main crop and $42.5 \mathrm{t} / \mathrm{ha}$ for ratoon crop, respectively was recorded under drip irrigation under $\mathrm{D}_{3} \mathrm{~F}_{3}$. Irrespective of plant or ratoon crop, maximum fruit yield was obtained under the treatment combinations of $\mathrm{D}_{3} \mathrm{~F}_{3}(43.5 \mathrm{t} / \mathrm{ha})$, which was followed by $\mathrm{D}_{2} \mathrm{~F}_{3}(43.3 \mathrm{t} / \mathrm{ha})$ and $\mathrm{D}_{2} \mathrm{~F}_{2}(42.6$ $\mathrm{t} / \mathrm{ha}$ ), which were at par with each other. The lowest yield was registered under surface irrigation treatments $(34.2 \mathrm{t} / \mathrm{ha}$ for $100 \%$ $\mathrm{RDF})$. When yields of $\mathrm{D}_{3} \mathrm{~F}_{3}$ and $\mathrm{SF}_{3}(34.2 \mathrm{t} / \mathrm{ha}$ for $100 \% \mathrm{RDF}$ ) were compared, $27 \%$ increment in the yield under drip fertigation was noted. This might be due to enhanced water utilization, higher nutrient uptakes and excellent maintenance of soil-water-air continuum with higher oxygen concentration in the root zone (Raina et al., 1999, 2011; Singandhupe et al., 2003) or influenced the root CEC increasing the nutrient uptake (Bangar and Chaudhari, 2004). The relatively lower fruit yield of ratoon crop than plant crop might be due to the additive effect of pre-planting application of FYM and the externally supplied NPK nutrients. Improved yields under drip fertigation with $\mathrm{N}, \mathrm{P}$ and $\mathrm{K}$ fertilizers has been also reported by many workers (Bharambe et al., 2001; Mahalakshmi, 2000; Kavino et al., 2002; Mahalakshmi et al., 2003; Rana et al., 2004).

In conclusions, the drip fertigation has positive effect on the yield attributes of the banana. It can be concluded that the yield of the banana can be increased remarkably by adopting drip fertigation. Easily available and cost effective fertilizers such as urea, MOP and DAP could be effectively utilized as nutrient source in the drip fertigation instead of using high analysis costly liquid fertilizers which in general are unavailable in rural market. The misuse of water due to either low efficiency of irrigation or inadequate irrigation scheduling can lead to higher production costs.

\section{Acknowledgement}

The authors are thankful to Department of Soil Science and Agricultural Chemistry, 
Bidhan Chandra Krishi Viswavidyalaya, Mohanpur, West Bengal for providing the facility and technical support to carry out this field experiment.

\section{References}

Allen, R. G., Pereira, L. S., Raes, D., and Smith, M. 1998. Crop evapotranspiration-guidelines for computing crop water requirements. Irrigation and Drainage Paper No. 56. FAO, Rome, Italy, p 300.

Badgujar, C. D., Deshmukh, S. S., Dusane, S. M. and Shide, S. S. 2004. Influence of ' $\mathrm{N}$ ' and ' $\mathrm{K}$ ' fertigation and different plant densities on yield of Banana cv. Grand Naine. South Indian Horticulture 52, 22-28.

Bangar, A. R. and Chaudhari, B. C. 2004. Nutrient mobility in soil, uptake, quality and yield of Suru sugarcane as influenced by drip fertigation in medium Vertisols. Journal of the Indian Society of Soil Science 52, 164-171.

Dahiwalkar, S. D., Divekar, B. K. and Sonawane, D. A. 2004. Relative performance of fertigation on growth, yield and quality of banana. Journal of Maharashtra Agricultural Universities 29(2): 235-237.

Doorenbos, J. and Pruitt, W. O. 1977. Crop water requirement. Irrigation and Drainage Paper No. 24, FAO, Rome.

Dorel, M., Achard, R., Tixier, P. and SIMBA, N 2008. Modeling nitrogen dynamics in banana populations in wet tropical climate. Application to fertilization management in the Caribbean. European Journal of Agronomy 29(1): $38-45$.

Goenaga, R and Irizarry, H. 1998. Yield of banana grown with supplemental dripirrigation on an Ultisol. Experimental Agriculture 34(4): 439-448.

Gomez, K. A. and Gomez, A. A. 1984.
Statistical procedures for agricultural research, John Wiley and Sons, Ink., New York.

Gottreich, M., Bradu, D. and Halevy, Y. 1964. A simple method for determining average banana fruit weight. Katvim 14, 161-62.

Kafkafi, U. and Kant, S. 2005. Fertigation. InEncyclopedia of soils in the environment (vol. II) (Ed. Daniel Hillel) Elsevier Ltd., pp. 1-9.

Kar, K. P. and Firake, N. N. 2002. Effect of water soluble fertilizers on growth and yield of banana. Journal of Maharashtra Agricultural Universities 26(3): 333334.

Kavino, M., Kumar, N., Soorianathasundaram, K. and Jeyakumar, P. 2002. Effect of source of fertilizers for fertigation on yield and quality of banana cv. Robusta (AAA). South Indian Horticulture 50(4-6): 301307.

Kumar, D. and Pandey, V. 2008. Effect of NPK fertigation on growth, yield and quality of banana 'Rasthali' (AABPathkapoora) in coastal agro-climatic conditions of eastern India. Indian Journal of Agricultural Sciences 78(9): 798-800.

Mahalakshmi, M., Kumar, N. and Soorianathasundaram, K. 2003. Effect of fertigation and irrigation on the yield of high-density plantations of $\mathrm{cv}$. 'Robusta'. Infomusa 12(1): 42-44.

Mahalakshmi, M., Kumar, N., Jayakumar, P. and Soorianathasundaram, K. 2001. Fertigation studies in banana under high density planting system. InProceedings of a National Seminar on Changing Scenario in the Production Systems of Horticultural Crops., Coimbatore, Tamil Nadu, India, 28-30 August 2001. South Indian Horticulture 49(Sp.): 86-91.

More, S. S., Shelke, R. D. and Kalyankar, S. 
P. 2005. Labour utilization and input use pattern in banana cultivation. Agricultural Marketing 48(1): 21 -23.

Raina, J. N., Tarika Sharma and Shashi Suman (2011) Effect of drip fertigation with different fertilizers on nutrient distribution in soil, leaf nutrient content and yield of apricot (Prunus aremeniaca L.). Journal of Indian Society of Soil Science 59, 268-277.

Raina, J. N., Thakur, B. C. and Verma, M. L. 1999. Effect of drip irrigation and polythene mulch on yield, quality and water use efficiency of tomato (Lycopersicon esculentum). Indian Journal of Agricultural Economics 69, 430-433.

Rana, S. K., Saha, S., Zaman, A., Goswami, B. S., Sarkar, S. and Mallick, S. 2004. Response of banana to drip irrigation in new alluvial zone of West Bengal. InProceedings of National Seminar on Banana Industry- Present Scenario and Future Strategies, 11-13 June 2004, BCKV., pp. 167-170.

Shelke, D. K., Vaishnava, V. G., Oza, S. R. and Jadhav, G. S. (1998. Management of irrigation in banana through drip irrigation systems. Journal of Maharashtra Agricultural Universities
23, 317-318.

Singandhupe, R. B., Rao, G. G. S. N., Patil, N. G. and Brahmanand, P. S. 2003. Fertigation studies and irrigation scheduling in drip irrigation system in tomato crop (Lycopersicon esculentum L.). European Journal of Agronomy 19, 327-340.

Singh, H. P. 2007. Production and utilization of banana for economics livelihood and nutritional security. In- Proc. National conference on banana. 25-26 Oct. 2007, NRCB. Trichi, Tamil Nadu., pp. 1-14.

Srinivas, K., Reddy, B. M. C., Kumar, S. S. C, Gowda, S. T., Raghupati, H. B. and Padma, P. 2001. Growth, yield and nutrient uptake of Robusta banana in relation to $\mathrm{N}$ and $\mathrm{K}$ fertigation. Indian Journal of Horticulture 58 (4): 287-293.

Vermeiren, I. and Jobling, G. A. 1980. Localized irrigation design, installation, operation and evaluation. Irrigation and Drainage Paper No. 36, FAO, Rome, 10-12.

Viers, F. G..Jr. 1972. Water deficits and plant growth. Vol. III (Ed. T.T. Kozlowskii). Academic press, Inc. New York and London.

\section{How to cite this article:}

Basanta Singh, T., S.K. Patra, Chongtham Tania, Ch. Premabati Devi, Thokchom Narjit Singh and Sorokhaibam Romio Singh. 2018. Effect of Drip Fertigation on the Yield and its Attributes of Banana (cv. Martaman-aab) in an Alluvial Soil. Int.J.Curr.Microbiol.App.Sci. 7(11): 25742582. doi: https://doi.org/10.20546/ijcmas.2018.711.293 